\title{
Konsep Blue Design dengan Sistem Rainwater Collects pada Apartemen High End
}

\author{
Putri Wulan Suci dan Ima Defiana \\ Departemen Arsitektur, Fakultas Arsitektur, Desain dan Perencanaan, Institut Teknologi Sepuluh Nopember (ITS) \\ e-mail: may.d@arch.its.ac.id
}

\begin{abstract}
Abstrak-Dalam kurun waktu terakhir, Surabaya telah melakukan berbagai pengembangan untuk memenuhi kebutuhan masyarakat seiring dengan meningkatnya jumlah populasi penduduk. Pengembangan kawasan properti, terutama kelas menengah atas, di kota Surabaya bergeser ke wilayah barat. Hal ini terlihat dari makin banyaknya pengembang besar yang membangun di Surabaya Barat dan menjadikan kawasan ini sebagai kawasan premium. Di sisi lain, dengan semakin terus bertambahnya jumlah penduduk, daya dukung lingkungan (air dan lahan) yang ada tetap sama atau bahkan lebih buruk. Kita sebagai manusia harus mampu mengikuti daya dukung lingkungan (air dan lahan) atau bahkan bisa membuatnya lebih baik untuk memenuhi kebutuhan dan keberlangsungan hidup. Dengan pendekatan Blue Design diharapkan memberikan solusi sistem pemakaian air hujan untuk memenuhi kebutuhan air yang saat ini semakin menipis yaitu dengan menangkap air hujan lalu disaring dan kemudian dimanfaatkan kembali untuk keperluan air sehari-hari. Desain apartemen mengusulkan dan mengolah air hujan secara maksimal sehingga berdampak positif pada bangunan dan lingkungan, konsep ekologi yang dicetuskan oleh Ken Yeang diterapkan pada apartemen dianggap sesuai menjadi solusi kebutuhan air tawar.
\end{abstract}

Kata Kunci-Daya Dukung Lingkungan, Surabaya, Pemanfaatan Air Hujan, Ekologi.

\section{PENDAHULUAN}

$\mathrm{K}$ OTA Surabaya merupakan kota metropolitan kedua setelah ibukota Indonesia, Jakarta. Berdasarkan data dinas tenaga kerja, kependudukan, dan transmigrasi Kota Surabaya pada tahun 2009 tingkat urbanisasi mencapai 2,66\% dan diperkirakan akan semakin bertambah hingga tahun 2029 [1]. Dengan pertumbuhan jumlah penduduk yang semakin meningkat membuat masyarakat di Surabaya menjadikan permintaan akan sumber air permukaan dan air tanah juga meningkat. Tercatat tahun 1983 kebutuhan air bersih 62,2 juta $\mathrm{m}^{3}$ dan tahun 2000 diperkirakan 323 juta $\mathrm{m}^{3}$ [2]. Menurut Edi Rusianto, Anggota Badan Pengawas (Bawas) PDAM Surya Sembada Surabaya Masyarakat Surabaya ini adalah masyarakat yang penggunaan airnya terbesar di Indonesia [3].

Data curah hujan berasal dari Stasiun Meteorologi Perak II menunjukkan data curah hujan harian maksimum selama 6 tahun [4]. Apabila hujan tidak tertangani dengan baik maka akan memberikan dampak negatif pada lingkungan, misalnya banjir. Namun, ternyata air hujan dapat berdampak positif pada bangunan jika dimanfaatkan dengan baik sesuai dengan peraturan Menteri Negara Lingkungan Hidup No. 12 tahun 2009 pasal 1 ayat 1 [5].

Hunian mempunyai konstribusi fisik yang terbesar pada lingkungan buatan dan terbanyak menempati ruang kota,

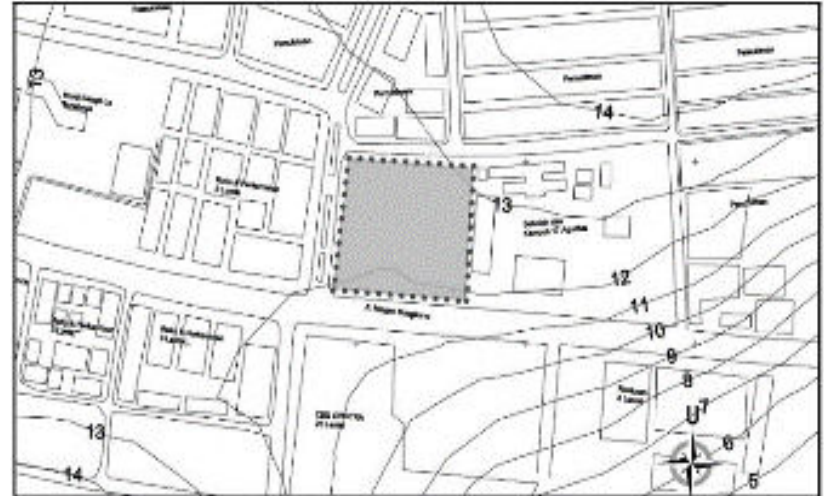

Gambar 1. Lokasi tapak bangunan di Jalan Mayjend Sungkono dengan luasan $\pm 22.743 \mathrm{~m}^{2}$

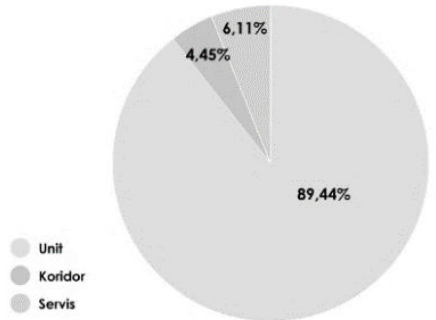

Gambar 2. Diagram persentase unit, koridor, servis dan rainwater system pada bangunan dari hasil survei apartemen.

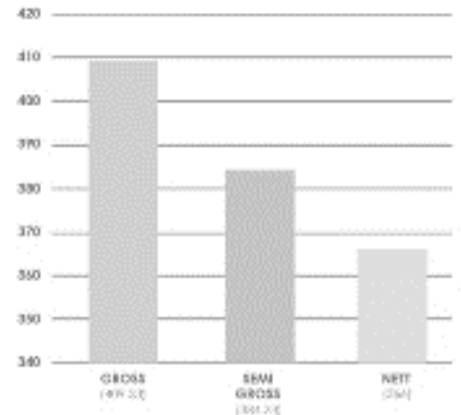

Gambar 3. Diagram persentase unit, koridor, servis dan rainwater system pada bangunan.

karena itu hunian di suatu kawasan berpengaruh terhadap keberlanjutan kota dan berperan besar dalam menciptakan pembangunan yang berkelanjutan [6]. Kajian ini bermaksud memanfaatkan potensi tapak dan iklim Surabaya yang memiliki curah hujan tinggi dengan mengadakan rainwater haversting pada bangunan untuk memenuhi kebutuhan air tawar sehari-hari penghuni apartemen dari sistem rainwater haversting. Oleh karena itu, kebutuhan air akan digantikan oleh air hujan. Dari kebutuhan tersebut kemudian ditotal untuk 
Tabel 1

Jenis dan Jumlah Unit Apartemen Blue Waterfall Habitat

\begin{tabular}{|c|c|c|c|}
\hline NO & TIPE UNIT & LUASAN UNIT & JUMLAH UNIT \\
\hline 1 & TIPE WINCHELL (2 Bedroom) & $194.5 \mathrm{~m}^{2}$ & 72 Unit \\
\hline 2 & TIPE COVENTINA (3 Becirom) & $245.4 \mathrm{~m}^{2}$ & 72 Unit \\
\hline 3 & TIPE AVAN [3 Bectrocm + 1) & $423,4 \mathrm{~m}^{2}$ & 40 Unit \\
\hline 4 & TIPE CASCATA (4 Bedroom) & $534.3 \mathrm{~m}^{2}$ & 18 Unit \\
\hline 5 & TIPE HINEWAI IPenthouse) & $764 \mathrm{~m}^{2}$ & 4 Unit \\
\hline & \multicolumn{2}{|c|}{ JUMLAH UNIT } & 206 Unit \\
\hline
\end{tabular}
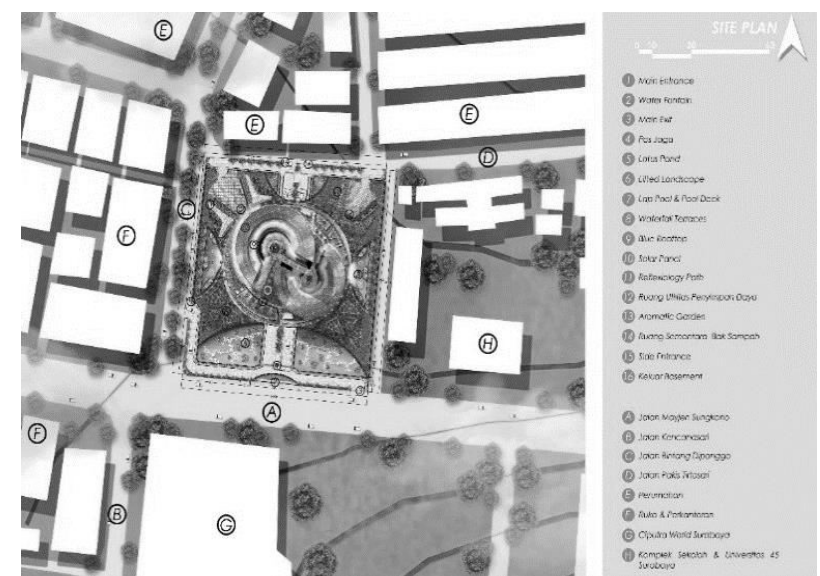

Gambar 4. Site plan apartemen yang terdiri dari area blue landscape, green landscape, tower bangunan, power house dan area pengolahan sampah.

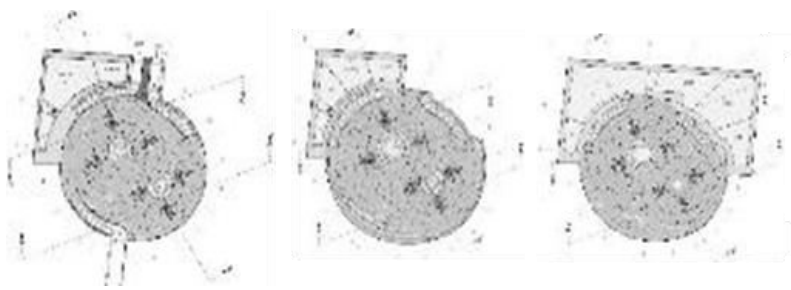

Gambar 5. Denah Basement 1, 2, dan 3 apartemen yang akan memuat 517 parkir mobil dan 175 motor. Selain parkir juga dilengkapi area power house, turbin, filtrasi dan reservoir bawah serta pompa air.

mendapatkan kebutuhan air hujan yang harus ditangkap per bulan. Setelah mengetahui total kebutuhan air dalam satu bulan yang akan digantikan oleh air hujan, selanjutnya dimasukkan ke rumus penghitungan penangkap air hujan untuk mendapatkan luas area tangkapan. Berikut adalah rumus perhitungannya [7]:

\section{Supply $($ in Gallons $)=$ Rainfall (inches) $x 0.623 \times$ Catchment Area (FT2) x Runoff Coefficient}

Dalam hal ini, bagaimana kebutuhan akan air tawar yang sangat tinggi pada apartemen high end dapat digantikan oleh air hujan. Sehingga apartemen terutama apartemen high end tidak lagi dilihat sebagai suatu kebutuhan primer ataupun sebuah pride untuk masyarakat kalangan menengah atas ataupun kalangan atas, tetapi juga sebagai suatu ruang untuk bernapas yang mampu meningkatkan kualitas daya dukung lingkungan melalui pemanfaatan air hujan sebagai pengganti kebutuhan air tawar yang selama ini di ambil dari air tanah. Untuk memenuhi kebutuhan air pada bangunan apartemen high end pada digunakan pendekatan Blue Design dengan metode Rainwater Harvesting.
Tabel 2.

Data Curah Hujan Surabaya Rata-Rata Total Tahun 2011-2016

\begin{tabular}{|c|c|c|c|c|c|c|c|c|}
\hline \multirow{2}{*}{ BULAN } & \multicolumn{6}{|c|}{ TAHUN } & \multirow{2}{*}{$\begin{array}{l}\text { RATA-RATA } / \\
\text { BULAN }(\mathrm{mm})\end{array}$} & \multirow{2}{*}{ inches } \\
\hline & 2011 & 2012 & 2013 & 2014 & 2015 & 2016 & & \\
\hline Januari & 174,50 & 312,10 & 477.70 & 272,10 & 436.60 & 284,10 & 326,18 & 12.84 \\
\hline Februari & 172.40 & 212.50 & 276.60 & 335.60 & 293.50 & 409,30 & 283.32 & 11.15 \\
\hline Maret & 375,00 & 311.40 & 322.40 & 186,00 & 243.80 & 163.10 & 266.95 & 10.51 \\
\hline April & 252,30 & 43,70 & 189,40 & 245,90 & 245,90 & 133,00 & 185,03 & 7,28 \\
\hline Mei & 78,90 & 75,00 & 159,40 & 54,80 & 109,70 & 358.80 & 139,43 & 5.49 \\
\hline Juni & 21,30 & 43,00 & 240.40 & 47,70 & 0,70 & 126.80 & 79,98 & 3,15 \\
\hline Juli & 1.60 & 0,00 & 103.00 & 4.00 & 0,00 & 90,10 & 33,12 & 1,30 \\
\hline Agustus & 0.00 & 0.00 & 0,00 & 4,80 & 0,00 & 38,20 & 7.17 & 0,28 \\
\hline September & 0.00 & 0.00 & 0.00 & 0.00 & 0,00 & 102,00 & 17,00 & 0,67 \\
\hline Oktober & 28.00 & 49.80 & 4.60 & 0.40 & 0.00 & 161.50 & 40.72 & 1,60 \\
\hline November & 181.50 & 82.90 & 90,30 & 69.00 & 130.20 & 117.90 & 111.97 & 4.41 \\
\hline Desember & 510.20 & 317.90 & 229,30 & 284.70 & 184.80 & 358,80 & 314.28 & 12,37 \\
\hline Rata-rata / tahun & 179,60 & 160.90 & 209,40 & 136,80 & 191,50 & 195,00 & 178,87 & 7,04 \\
\hline
\end{tabular}
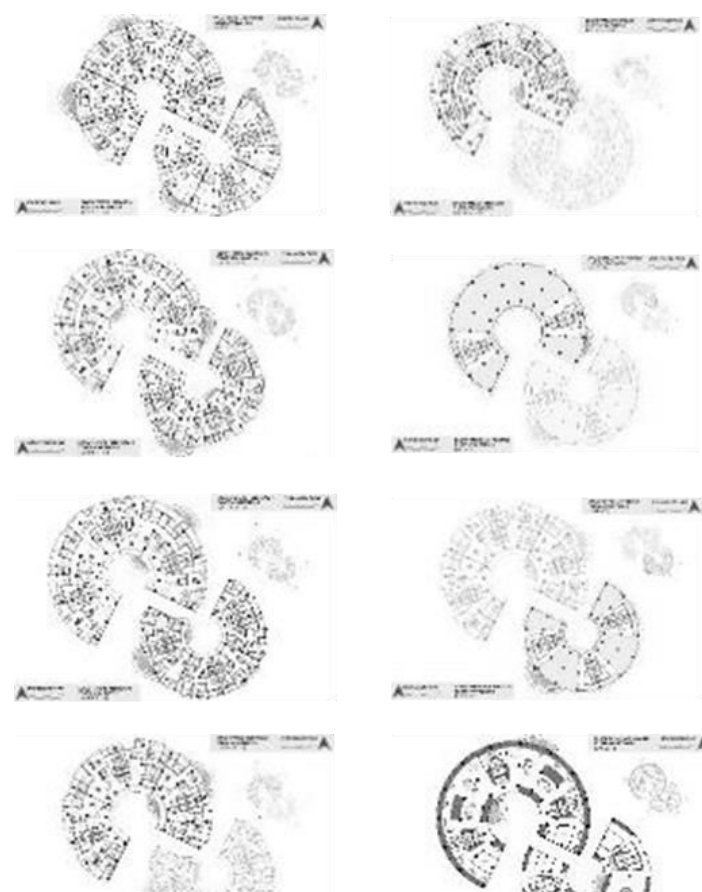

A.t.e smpr
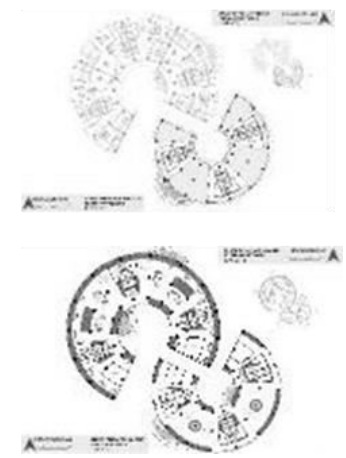

Gambar 6. Denah tipikal apartemen Blue Waterfall Habitat.

Dari hasil perhitungan data curah hujan di Surabaya selama 6 tahun terakhir maka diperoleh luasan area yang dibutuhkan untuk menangkap air hujan pada site adalah $213130 \mathrm{ft}^{2}$ atau $19800 \mathrm{~m}^{2}$. Untuk volume tangki penampungan supply air hasil tangkapan disesuaikan dengan kebutuhan penyimpanan terbesar pada tahun pertama di bulan Mei yaitu sekitar 9406556 liter. Maka daya tampung tangki penyimpanan diharapkan mempunyai volume $9406 \mathrm{~m}^{3}$. Volume ini kemudian berpengaruh pada hasil desain apartemen baik dari landsekapnya hingga rooftop apartemen yang ditunjukkan melalui gambar siteplan dan denah pada Gambar 4.

\section{METODE PERANCANGAN}

Framework yang digunakan untuk mendukung rancangan ini adalah Force Based Method yang diambil dari buku Revealing Architecture Design oleh Philip D Plowright [8]. Force Based Method adalah adalah framework dalam mendesain yang menyesuaikan constraint yang ada. Dengan site yang ada yaitu di dataran rendah dengan curah hujan yang tinggi dan tingginya kepadatan penduduk yang memicu keterbatasan air tawar maka melalui Force Based Method 
ditemukan objek arsitektural yang sesuai dengan isu tersebut

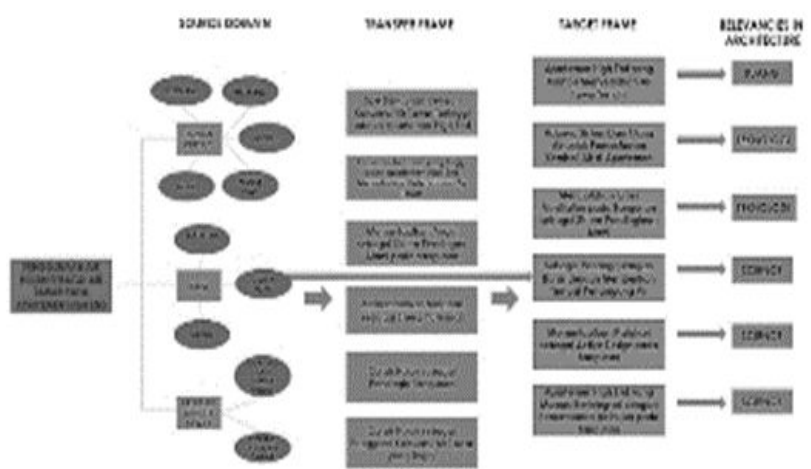

Gambar 7. Domain to Domain Transfer dengan Force Based Method. Sumber: Penulis (2017) dari olahan Revealing Design: Plowright (2014).

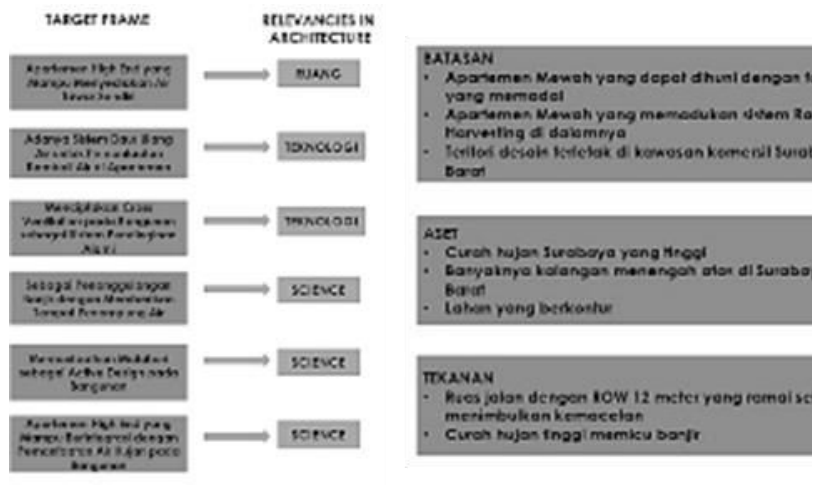

Gambar 8. Bagan Integrasi Domain to Domain Transfer dengan Force Based Method. Sumber: Penulis (2017) dari olahan Revealing Design: Plowright (2014).

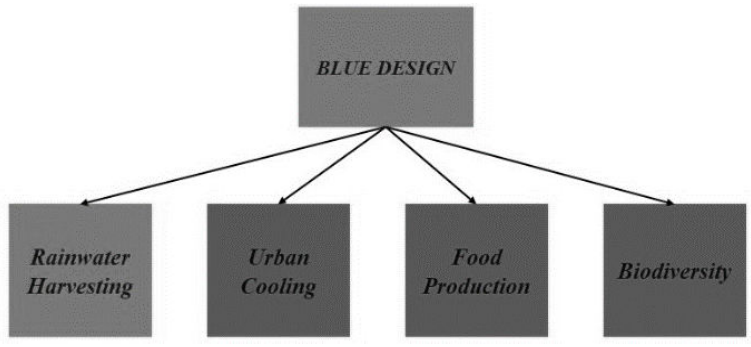

Gambar 9 Diagram Pemanfaatan Blue Design.

(Sumber : Permavoid, The Fondation of Our Future. (2017). Blue Green Roof. Diperoleh 23September 2017, dari http://www.permavoid.co.uk/solutions/blue-green-roofs/)

sebagai solusinya [8]. (Ditunjukkan melalui Gambar 7 dan 8).

Blue Design merupakan penggabungan pengelolaan air dan ruang hijau untuk saling melengkapi, mengurangi kebutuhan akan infrastruktur beton yang lebih mahal, sekaligus memperbaiki kondisi lingkungan setempat dan mempersiapkan bangunan dengan lebih baik untuk menyesuaikan diri dengan tantangan perubahan iklim [9]. (Ditunjukkan pada gambar 9).

Blue services meliputi: perlindungan banjir, persediaan air (untuk irigasi, air minum, pengendalian penurunan tanah), rekreasi air, dan pengumpulan energi termal, transportasi dan penyimpanan, ruang untuk tinggal dan bekerja di atas air, lansekap, habitat untuk perairan dan terestrial spesies dan layanan budaya (kesehatan fisik, estetika, spiritual), peraturan iklim (iklim yang setara), detoksifikasi dan pemurnian air

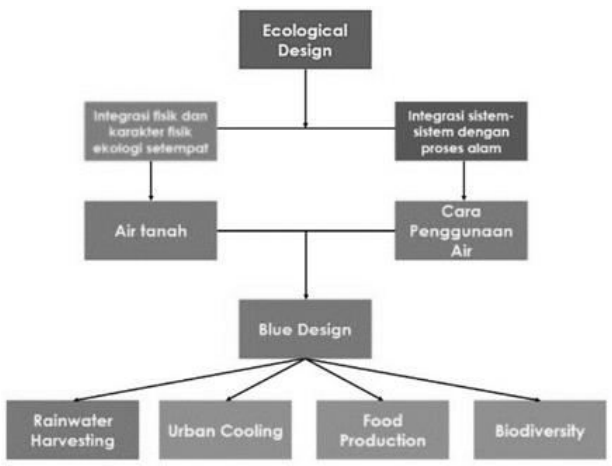

Gambar 10. Bagan Integrasi Ekological Design dan Blue Design. Sumber: Penulis (2014) dari Olahan Designing with Nature: Ken Yeang (1995).

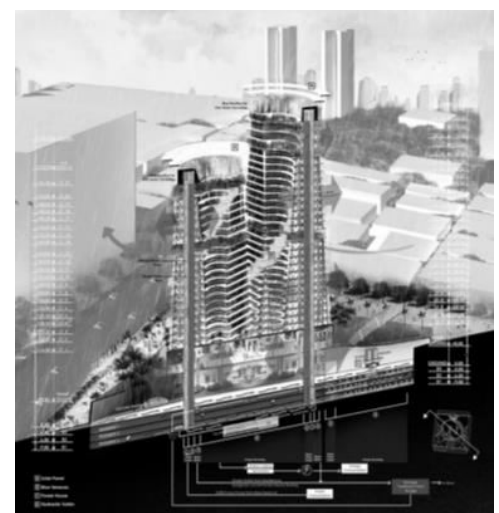

Gambar 11. Diagram penjelasan sistem utilitas.

(pengendalian pencemaran) dan peraturan bahaya [9]. Fungsi utama komponen infrastruktur Blue-Green meliputi:

1. penggunaan / penggunaan kembali air,

2. pengolahan air,

3. penahanan dan infiltrasi,

4. evapotranspirasi,

5. pengembangan berbagai habitat yang layak untuk ekosistem lokal

6. pengelolaan yang lebih baik dari penyediaan air hujan dan air, konservasi sumber daya air melalui efisiensi (meningkatkan ketahanan terhadap kekeringan)

7. pengurangan / mitigasi karbon

8. kontrol pencemaran air

Sesuai dengan pendekatan yang diambil yaitu Blue Design, tentang bagaimana mengatasi dan mengolah air hujan secara maksimal maka konsep ekologi dianggap sesuai untuk mendukung laporan ini akan menggunakan konsep yang dicetuskan oleh Yeang yang biasanya didesain pada bangunan high rise [10]. Konsep ini akan menjadi tolak ukur perancangan (parameter) apartemen untuk menemukan bentuknya. Pemilihan parameter telah dirangkum menjadi tujuh parameter yang telah diklasifikasikan berdasarkan standar bangunan apartemen dan kebutuhan terhadap bangunan itu sendiri [11]:

1. Orientasi

2. Bukaan jendela

3. Lansekap

4. Desain dinding

5. Transisi 
6. Pembayangan Pasif

7. Open plan
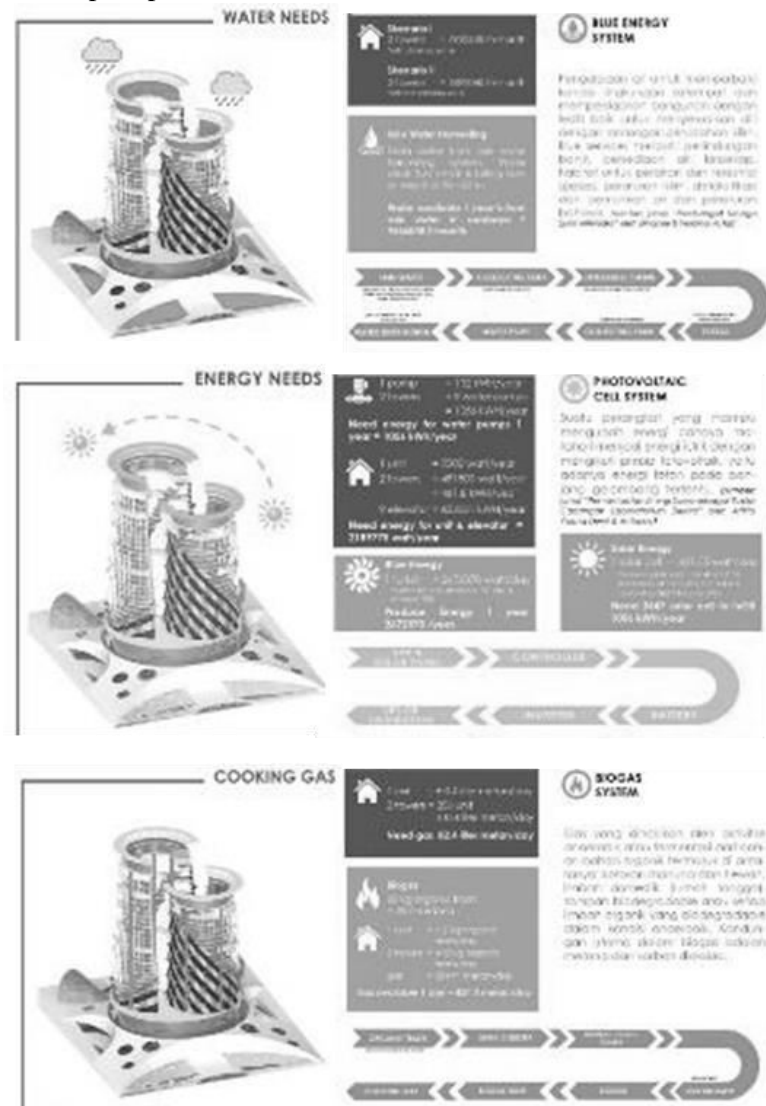

Gambar 12 Diagram Building Features. (Sumber : Dewi, Arfita Yuana., dan Antonov. (2013), Pemanfaatan Energi Surya sebagai Suplai Cadangan pada Laboratorium Elektro Dasar di Institut Teknologi Padang. Padang: Institut Teknologi Padang \& Erhaneli., Ferdinal Rustaf. (2013), Pembangkit Tenaga Listrik Minihidro di Desa Guguak Ampek Padang Kecamatan 2x11 Kayu Tanam Kabupaten Padang Pariaman. Padang: Fakultas Teknik Industri Institut Teknologi Padang).

Integrasi parameter ekologi Ken Yeang dan Blue Design. (Ditunjukkan pada Gambar 10). Diagram pemanfaatan Blue Design dapat dilihat pada Gambar 9.

\section{HASIL DAN EKSPLORASI}

Proses eksplorasi desain memiliki banyak faktor yang harus diperhatikan, tidak hanya dari segi konsep tetapi juga eksplorasi teknis. Eksplorasi teknis pada desain merupakan integrasi antara beberapa elemen desain seperti aspek formal (bentuk), ruang dalam, struktur dan utilitas. Integrasi struktur dan utilitas bangunan menjadi awal yang sangat penting untuk mendukung konsep bangunan yaitu Blue Design pada rancangan apartemen ini mulai dari struktur dan material pada tower apartemen, landscape hingga building utility sebagai area penyimpan \& pengolah energi pada bangunan. Hal ini juga menjadi dasaran penting untuk eksplorasi formal.

Integrasi dengan utilitas bangunan menjadi sangat penting karena disesuaikan juga dengan konsep \& pendekatan yang digunakan yaitu Blue Design. Maksudnya adalah energi yang mendukung bangunan berasal dari energi biru (air) yang berasal dari air hujan untuk menunjang kebutuhan air tawar pada bangunan. Kemudian dari energi biru ini juga dapat menjadi trigger pemenuh kebutuhan lain pada bangunan seperti listrik \& biogas [12][13]. (Ditunjukkan pada Gambar 10).

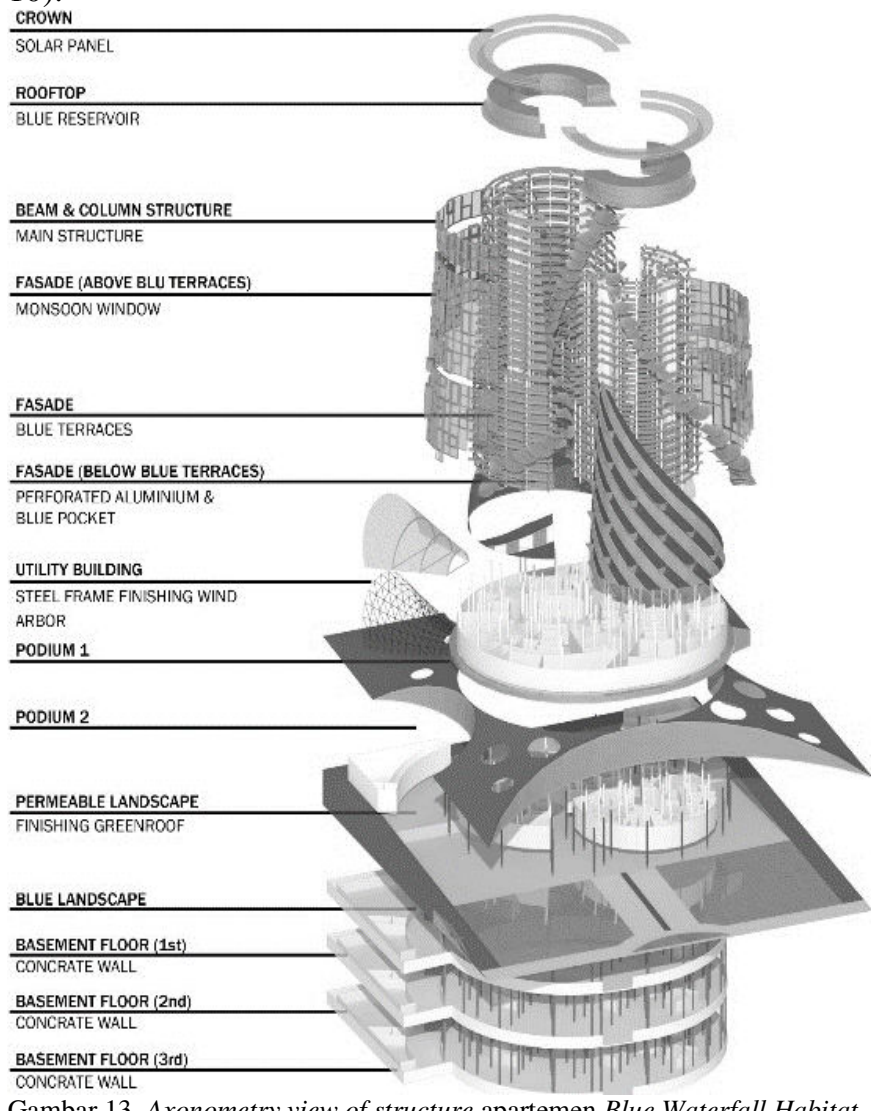

Gambar 13. Axonometry view of structure apartemen Blue Waterfall Habitat.

Bangunan dirancang sedemikian rupa sehingga mampu untuk menampung air hujan sebanyak mungkin pada bangunan ketika musim hujan dan melalui air hujan tersebut mampu membangkitkan dan meng-cover kebutuhan listrik pada apartemen selain pompa air dengan bantuin turbin hidrolik. Sedangkan pada musim kemarau bangunan juga dirancang supaya tetap mampu mengalirkan air hujan yang disimpan dari musim hujan tersebut sehingga menghasilkan listrik ketika air tersebut jatuh mengenai turbin hidrolik dengan bantuan panel surya untuk memompa air tersebut ke atas. Oleh karena itu terdapat empat area penting untuk menangkap hujan pada bangunan yaitu Blue Rooftop, Blue Terraces, Blue Pocket dan Blue Landscape.

Kembali kepada fungsi utama pengumpulan air pada bangunan yaitu untuk memenuhi kebutuhan air tawar baik itu minum, mandi, mencuci pakaian, mencuci piring, irigasi lansekap, fasilitas penunjang apartemen (kolam renang hingga jacuzzi) ataupun kebutuhan untuk air hidran. Air Hujan yang dikumpulkan akan bertemu dengan grey water dan difilter dengan bantuan katalis untuk mempercepat proses filtrasi air untuk selanjutnya digunakan kembali dalam pemenuhan kebutuhan air tawar pada bangunan. Sedangkan black water akan menuju septic tank untuk selanjutnya diolah menjadi biogas yang terletak di ruang pengolahan sampah. (Ditunjukkan pada Gambar 10).

Sistem penghawaan pada bangunan juga dibuat untuk mendukung pendekatan Blue Design sekaligus konsep Ekologi dari Ken Yeang yang memaksimalkan penghawaan alami pada 
bangunan meskipun hari hujan. Oleh karena itu, untuk konsep rancangan pada jendela dibuat dengan sistem Monsoon Window (jendela horisontal) sehingga tetap dapat memungkinkan pertukaran udara di dalam ruangan tanpa

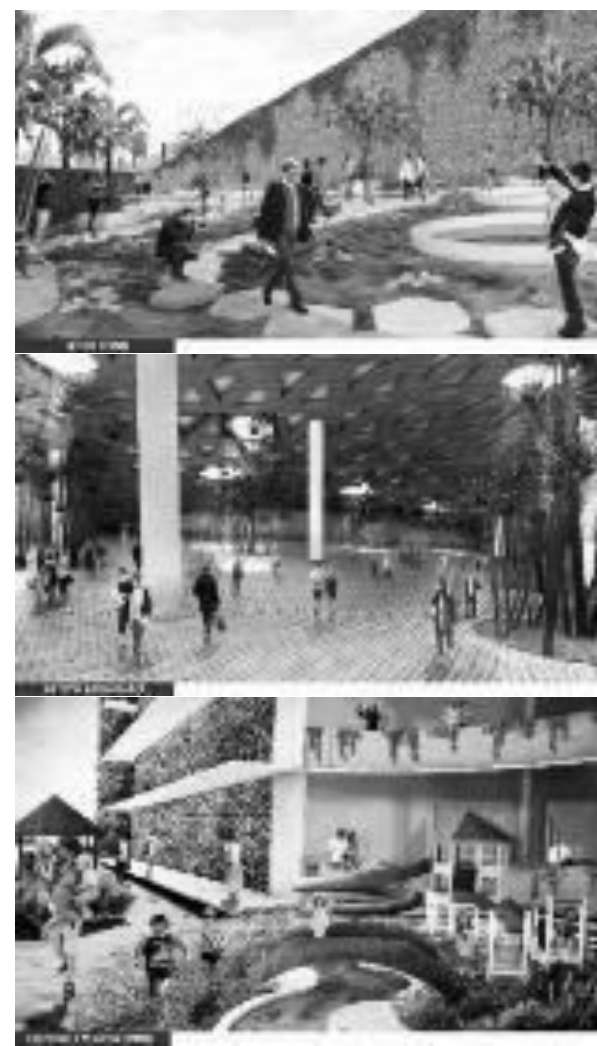

Gambar 14. Fasilitas pendukung apartemen yaitu Lotus Pond, Playground Outdoor dan Lifted Landscape.

memasukkan air hujan ke dalam ruangan meskipun hari hujan dengan memasukkan prinsip cross-ventilation dalam perencanaannya. Berikut adalah diagram siklus air hujan pada bangunan yang menjadi dasar 3 features penting yang mendukung bangunan seperti water needs, energy needs dan cooking gas [13][12] (Gambar 11).

Hal lain yang diperhatikan dalam perancangan bangunan adalah struktur bangunan. Struktur bangunan harus mampu men-support pendekatan bangunan yang diimplementasikan pada bangunan yaitu Blue Design dalam empat features bangunan yaitu terutama pada Blue Rooftop, Blue Terraces, Blue Pocket dan Blue Landscape. Selain men-support empat features penting pendukung Blue Design pada bangunan juga ditentukan struktur dan material yang disesuaikan dengan konsep ekologi yang juga di aplikasikan pada bangunan (Gambar 13).

Tidak hanya dari segi struktur bangunan, dengan tipologi bangunan yang merupakan apartemen high end tentunya bangunan harus mampu memiliki beberapa fasilitas penunjang yang mampu untuk meng-entertaint penghuninya dengan tetap mengaplikasikan pendekatan Blue Design dan konsep ekologi pada bangunan. Terutama adalah fasilitas pada area lansekap bangunan (Gambar 14):

1. Lotus Pond, sesuai dengan konsep bangunan "Blue Design" dimana bangunan harus mampu menampung sebanyak mungkin air maka landsekap bangunan dibuat sedapat mungkin untuk bisa menampung air hujan. Oleh karena itu dibuatlah sebuah kolam pada lansekap apartemen yang juga memiliki secondary function sebagai fasilitas pendukung apartemen sehingga dibuatlah "Lotus

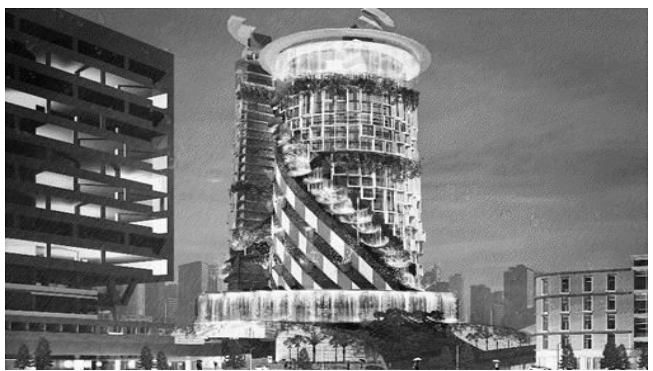

Gambar 15. Perspektif mata normal dari apartemen Blue Waterfall Habitat.

Pond" pada lansekap apartemen.

2. Lifted Landscape, untuk mempertahankan konsep "Blue Design" pada lansekap tetapi tetap menyediakan area hijau pada lansekapnya maka dipilih penyelesaian lansekap berupa "Lifted Landscape" yaitu landscape yang diangkat sehingga area dibawah lansekap yang terangkat dapat digunakan baik untuk menyerap air atau pun parkir pengunjung apartemen. Tanaman yang kemudian dipilih pada lifted landscpe ini adalah tanaman "Cyperus Papirus".

3. Outdoor Playground, apartemen merupakan rumah yang berada di dalam gedung. Oleh karena itu diperlukan beberapa fasilitas penunjang kegiatan di apartemen supaya penghuni merasa nyaman dengan tetap mempertahankan konsep "Blue Design". Salah satu fasilitas penunjangnya adalah outdoor playground yang terletak di rooftop podium apartemen. Playground juga dilengkapi dengan kolam air yang dapat digunakan sebagai area bermain untuk anakanak.

\section{KESIMPULAN}

Air hujan merupakan sumber air tawar yang berlimpah dan gratis. Mengapa kita tidak menjadikannya sebagai sumber energi pada bangunan kita? Seiring bertambahnya jumlah penduduk, maka daya dukung lingkungan (air dan lahan) tetap sama atau bahkan lebih buruk. Kita sebagai manusia harus mampu mengikuti daya dukung lingkungan (air dan lahan) atau bahkan bisa membuatnya lebih baik untuk memenuhi kebutuhan dan keberlangsungan hidup. Blue Waterfall Habitat adalah sebuah trigger sekaligus sebuah cara serta solusi untuk memenuhi kebutuhan manusia (berupa hunian) yang tidak merusak lingkungan tetapi bisa memperbaiki lingkungan tersebut dengan menggunakan sumber energi biru.

\section{DAFTAR PUSTAKA}

[1] Dinas Perhubungan Kota Surabaya, "Rencana Pembangunan Jangka Menengah Daerah Kota Surabaya. (2011-2015),” Surabaya.

[2] M. Wibowo, "Potensi Sumber Daya Air Tanah di Surabaya berdasarkan Survei Geolistik Tahanan Jenis," Bandung, 2001.

[3] detik.com, "Konsumsi Air di Kota Surabaya Tertinggi dibandingkan Nasional. Sumber." [Online]. Available: https://news.detik.com/jawatimur/3463712/konsumsi-air-di-kotasurabaya-tertinggi-dibandingkan-nasional. [Accessed: 29-Sep2017].

[4] Badan Meteorologi Klimatologi dan Geofisika, "Data Curah Hujan 
Stasiun Meteorologi Perak II Surabaya,” Surabaya, 2017.

[5] R. Witoelar, "Peraturan Menteri Negara Lingkungan Hidup Nomor 12 Tahun 2009 tentang Pemanfaatan Air Hujan," Jakarta, 2009.

[6] L. Chandra, S. Wijaksono, and S. Kusdiwanggo, "Analisis Kebutuhan Air Harian Penghuni Apartemen Sewa dengan Pemanfaatan Air Hujan di Kawasan Grogol Jawa Barat," Jakarta, 2012.

[7] P. H. Waterfall, Harvesting Rainwater for Landscape Use, 2nd ed. Tucson: Arizona Department of Water Resources, 2006.

[8] P. D. Plowright, Revealing architecture design: Methods, Frameworks and Tools. New York: Routledge, 2014.

[9] Blue Green Solutions, "Blue Green Dream Concept," 2015. .
[10] K. Yeang, Designing with Nature: The Ecological Basis for Architectural Design. United State of America: Mc Graw Hill, 1995.

[11] K. Yeang, Bioclimatic Skyscrapers. London: Artemis, 1994.

[12] Erhaneli and F. Rustaf, "Pembangkit Tenaga Listrik Minihidro di Desa Guguak Ampek Padang Kecamatan 2x11 Kayu Tanam Kabupaten Padang Pariaman," Padang, 2013.

[13] A. Y. Dewi and Antonov, "Pemanfaatan Energi Surya sebagai Suplai Cadangan pada Laboratorium Elektro Dasar di Institut Teknologi Padang," Padang, 2013. 